\title{
Neural bystander damage by infiltrating virus- infected $T$ cells and the cytotoxic $T$ lymphocytes in HTLV-I-associated neurological disease
}

\author{
Eiji Matsuura1*, Ryuji Kubota², Yuetsu Tanaka ${ }^{3}$, Hiroshi Takashima', Shuji Izumo ${ }^{2}$ \\ From 15th International Conference on Human Retroviruses: HTLV and Related Viruses \\ Leuven and Gembloux, Belgium. 5-8 June 2011
}

We hypothesized that the cytotoxic $\mathrm{T}$ lymphocytes (CTLs) play a pivotal role in the pathogenesis of human T lymphotropic virus type I (HTLV-I)-associated myelopathy/tropical spasticparaparesis(HAM/TSP).

One of the most striking features of the cellular immune response in the patients with HTLV-I-associated myelopathy/tropical spastic paraparesis (HAM/ TSP) is the highly increased numbers of HTLV-I-specific cytotoxic T lymphocytes (CTLs) in the circulation of the blood and the cerebrospinal fluid, nevertheless HTLV-I proviral load in the PBMC remains high in the patients.

To determine the CTL's association with the pathogenesis of HAM/TSP in the CNS, we developed novel methods of in-situ detection for HTLV-I-specific CTL using HLA/antigen peptide tetramer and for the cells expressing HTLV-I viral protein. We visualized the HTLV-I specific CTLs and HTLV-I-infected cells in autopsied spinal cords of the patients with HAM/TSP.

We demonstrated that HTLV-I-specific CTLs expressing cytotoxic molecules accumulated in the spinal cords from three patients with HAM/TSP and that HTLV-I exclusively infected CD4 positive T lymphocytes but neither resident cells nor macrophages. The phenotype of apoptotic cells was HTLV-I infected CD4+ T lymphocytes or HTLV-I non-infected oligodendrocytes.

The findings suggest a unique pathogenesis for the neuroinflammatory disease that an inflammation of the central nervous system is attributed to the interaction

\footnotetext{
* Correspondence: pine@m.kufm.kagoshima-u.ac.jp

'Department of Neurology and Geriatrics, Kagoshima University Graduate School, Kagoshima, Japan

Full list of author information is available at the end of the article
}

between HTLV-I-infected CD4+ T cells and HTLV-Ispecific CD8+ CTLs from the periphery.

\section{Author details}

'Department of Neurology and Geriatrics, Kagoshima University Graduate School, Kagoshima, Japan. ${ }^{2}$ Center for Chronic Viral Disease, Kagoshima University Graduate School, Kagoshima, Japan. ${ }^{3}$ Department of Immunology, University of the Ryukyus, Okinawa, Japan.

Published: 6 June 2011

doi:10.1186/1742-4690-8-S1-A120

Cite this article as: Matsuura et al: Neural bystander damage by infiltrating virus-infected T cells and the cytotoxic T lymphocytes in HTLV-I-associated neurological disease. Retrovirology 2011 8(Suppl 1): A120.

Submit your next manuscript to BioMed Central and take full advantage of:

- Convenient online submission

- Thorough peer review

- No space constraints or color figure charges

- Immediate publication on acceptance

- Inclusion in PubMed, CAS, Scopus and Google Scholar

- Research which is freely available for redistribution

Submit your manuscript at www.biomedcentral.com/submit
C Biomed Central

\section{Biomed Central}

